\title{
Pengembangan Karakter Multikultural Santri Pada Pondok Pesantren Salafiyah di Kalimantan Selatan
}

\author{
Nadzmi Akbar* Muhammad Rifat** \\ * Bimbingan dan Penyuluhan Islam, Fakultas Dakwah dan Ilmu Komunikasi, \\ Banjarmasin, Indonesia **Bimbingan dan Penyuluhan Islam, Fakultas Dakwah dan \\ Ilmu Komunikasi, Banjarmasin, Indonesia \\ *Email; nadzmiakbar@uin-antasari.ac.id **Email; rifat.iain@gmail.com
}

\begin{abstract}
At the national policy of the Republic of Indonesia in 2010-2025 to prioritize the development of national character, because the Indonesian people at this time the values start from national identity, higher, contradictory, towards people of different religions, ethnicities and cultures. To build this character, the world of education is the backbone to carry out the mission of building multicultural characters of Indonesian citizens. Salafi Islamic Boarding School or Islamic Boarding School is one of the educational institutions in Indonesia, which also has an obligation to build the multicultural character of the students. How did the Salafiyah Islamic Boarding School develop the multicultural character of the students? The research method in this research is descriptive qualitative, data collection techniques with observation, interviews and documentaries. The results of this study found that the development of multicultural character in Salafiyah Islamic boarding school in an integrated manner in the field of moral education in an integrated manner, the organizational culture of the Salafiyah Islamic boarding school could develop the multicultural character of students, leaders, chaplains and teachers help display a very important practice for guests.
\end{abstract}

KEYWORDS Character Development; Multicultural; Islamic boarding school 
ABSTRAK

Dalam kebijkan nasional Republik Indonesi tahun 2010-2025 mengarus utamakan pembangunan karakter bangsa, sebab bangsa Indonesia saat ini nilai mulai kehilangan jatidiri bangsa terutama sikap saling menghargai terhadap orang yang berbeda agama, suku dan budaya. Untuk membangun karakter tersebut, dunia pendidikan menjadi tulang punggung untuk menjalankan misi pembangunan karakter multikultiral warga negara Indonesia. Pondok Pesantren Salafi atau Pesantren tradisional adalah salah satu lembaga pendidikan yang ada di Indonesia juga mempunyai kewajiban membangun karakter multikultural para santri. Bagaimana Pondok Pesantren Salafiyah mengembangkan karakter multikultural para santri? Metode penelitian dalam penelitian ini adalah diskriptif kualitatif, teknik pengumpulan datanya dengan observasi, wawancara dan dokumenter. Hasil peneltian ini menemukan bahwa pengembangan karakter multikultural di pondok pesantren salafiyah secara ekplesit direncanakan pada aspek pendidikan akhlak secara terpadu, budaya organisasi pondok pesantren salafiyah memungkinkan berkembangnya karakter multikultural santri, para pemimpin, para kiyai dan para guru selalu menampakan prilaku dengan nilai-nilai menghormati orang lain terutama para tamu dan menghargai perbedaan.

KATA KUNCI Pengembangan Karakter; Multikultural; Pondok Pesantren

\section{Pendahuluan}

Dalam kebijakan Nasional Pembangunan Karakter Bangsa yang dikeluarkan oleh Pemerintah Republik Indonesia (2010) menyimpulkan bahwa bangsa Indonesia saat ini mulai kehilangan jati diri, nilai-nilai kebersamaan, kegotongroyongan, musyawarah mufakat sikap adil sudah mulai luntur. Secara individual sikap hormat, menghargai perbedaan dan menerima perbedaan juga sudah mulai tercerabut dari sendi-sendi kehidupan bangsa Indonesia. Menilik sejarah dan realita saat ini beberapa kali tragedi kemanusiaan yang terjadi merupakan bersumber dari perbedaan suku, agama dan budaya. Sebagaimana terjadi tahun 2001 terjadi kerusuhan di Sampit Kalimantan Tengah, kerusuhan Tarakan tahun 2010, pada 4 Juli 2011. Karakter multikulturalis harus menjadi perhatian bagi semua pihak apalagi bangsa Indonesia yang memiliki khazanah perbedaan yang sangat banyak dan unik. Jika dikelola dengan baik akan menjadi potensi kekayaan yang luar biasa bagi Indonesia, tetapi jika dilupakan begitu saja akan menjadi bencana yang sangat dahsyat.

Perbedaan dalam kehidupan manusia tidak akan bisa dipungkiri, sebagaimana firman Allah SWT "Hai manusia, Sesungguhnya kami menciptakan kamu dari seorang laki-laki dan seorang perempuan dan menjadikan kamu berbangsa - bangsa dan bersuku-suku supaya kamu saling kenal-mengenal. 
Sesungguhnya orang yang paling mulia diantara kamu disisi Allah ialah orang yang paling taqwa diantara kamu.Sesungguhnya Allah Maha mengetahui lagi Maha Mengenal." (QS. al-Hujurat (49): 13).Dalam Islam sudah diajarkan tentang multikulturalisme dan bagaimana bersikap, Hai orang-orang yang beriman, jauhilah kebanyakan dari prasangka, sesungguhnya sebagian prasangka itu adalah dosa dan janganlah kamu mencari-cari kesalahan orang lain dan janganlah sebahagian kamu menggunjing sebahagian yang lain. Q.S. al-Hujurat (49): 12.

Menerima perbedaan dalam kebersamaan akan memberikan dampak kedamaian, kerukunan dan saling tolong menolong. Konsep rahmatan lil alamin yang mendatangkan kebaikan pada semua orang akan dapat terimplikasi dengan baik ditengah-tengah masyarakat yang multikultural. Universalisme Islam salah satu ujud dari agama yang rahmatan lil'alamin, menurut A. Boisard (1980: 183-1920 empat aspek utama universalisme Islam dantaranya prinsipprinsip moral dapat diterapkan di lingkungan dengan kultur berbeda-beda. Kemudian Islam menghargai perbedaan dengan mengedepankan prinsip harmonis, bukan ketakaburan. Pada sisi lain Muhammad Iqbal menyatakan bahwa kemunduran kaum Muslimin bukanlah disebabkan ajaran agamanya, tetapi kesalahan terletak pada diri masing-masing pribadinya. Mereka keliru dalam memahami ajaran agama lantaran kejumudannya, sangat ironis mengembangkan fahamnya dengan cara apapun (Rasyid, Muhammad Makmun. 2016). Pada aspek sosial dan muamalah. Islam hanya berbicara ketentuanketentuan dasar dan pilar-pilarnya saja. Operasional dan pelaksanaannya diserahkan kepada kesepakatan bersama dan lokalitas tempat tumbuh kembangnya sebuah hukum (Muzadi. A. Hasyim. 2002). Dalam konteks menghadapi era industri diperlukan pola pikir dan karakter multikultural yang dapat menerima perbedaan dan menumbuhkan kreativitas anak bangsa.

Dunia pendidikan menjadi tumpuan dan harapan pemerintah untuk dapat membentuk dan mengembangkan karakter multikultural masyarakat, baik pendidikan formal maupun non forrmal. Pondok pesantren merupakan salah satu lembaga pendidikan yang juga terus menerus mengembangkan karakter para santrinya. Pendidikan pada pondok pesantren ada yang bersifat formal dan ada juga yang non formal, sehingga arah dan bentuk pendidikan dalam pondok 
pesantren sepenuhnya di tentukan oleh pimpinan pondok pesantren bersangkutan. Setiap pesantren mempunyai gaya dan strategi tersendiri dalam membentuk karakter para santrinya. Penelitian Najmina, N (2018) menunjukan bahwa pendidikan mmultikultural harus dimulai dari pembentukan pola pikir, terimplementasi dalam sikap dan tindakan yang terbiasa sehingga menjadi karakter.

Berabagai strategi dapat dilakukan dalam membentuk karakter multikultural, baik dilakukan secara explisit maupun implisit. Model atau contoh tauladan yang ditempilkan oleh orang-orang di sekitar memiliki peran besar membentuk karakter anak. Pendidikan karakter berbasis multikultural dapat diterapkan melalui bahan ajar yang dikembangkan adalah bahan ajar yang bermuatan karakater multikultural dapat juga diambil dari berbagai tradisi masyarakat Indonesia yang dekat dengan lingkungan peserta didik serta mengandung nilai-nilai karakter dalam budaya lokal (Rinjani, Ersila Devy : 2017)

Di Kalimantan Selatan banyak sekali pondok pesantren sebagai tempat pendidikan Islam bagi anak, termasuk di dalamnya memberikan pendidikan budipekerti atau akhlak mulia yang juga disebut dengan karakter. Dari pengamatan di lapangan pada tiga pondok pesantren al Falah, pondok pesantren Ibnul Amin dan pondok pesantren Darussalam, dari informasi-informasi yang berkembang para santri dan lulusan pondok pesantren tersebut memiliki karakter yang baik, ditinjau dari aspek emosional dan sosial. Para santri dan alumnusnya dipandang memiliki karakter multikultural menghargai orang lain, rasa hormat pada orang lain, menerima perbedaan, toleransi, cinta tanah air dan dapat hidup bahagia dalam alam demokrasi Indonesia.

Berdasarkan uraian tersebut di atas, tentunya pihak manajemen pesantren memiliki pendekatan dan strategi tertentu dalam membentuk dan mengembangkan karakter multikultural para santrinya. Untuk itulah perlu dilakukan penelitian secara mendalam tentang strategi pemimpin pondok pesantren membentuk karakter multikultural santri membentuk karakter multikultural para santrinya, dimulai dari perencanaan kemudian strategi yang dilakukan dalam membentuk karakter multikultural di pondok pesantren salafiah. 


\section{Metode Penelitian}

Penelitian ini akan menggunakan metode kualitatif, untuk dapat menggambarkan dan mendiskripsikan tentang strategi membangun karakter multikultural santri di Pondok Pesantren slafiah.. Seluruh fenomena yang ada di lapangan disajikan dalam bentuk uraian diskriptif secara utuh sampai kepada kesimpulan-kesimpulan bagaimana sebenarnya strategi membangun karakrer multikultural santri di tempat penelitian. Teknik pengumpulan data menggunakan wawancara, observasi dan dokumenter. Rancangan penelitian ini adalah dengan multisitus, yaitu melakukan penelitian pada tiga lokasi penelitian yang berbeda yang dimulai dengan analisis tunggal kemudian semua situs dianalisis secara keseluruhan, sehingga diperoleh kesamaan dari ketiga situs tersebut.

Teknik analisis data dapat digambarkan sebagai berikut:

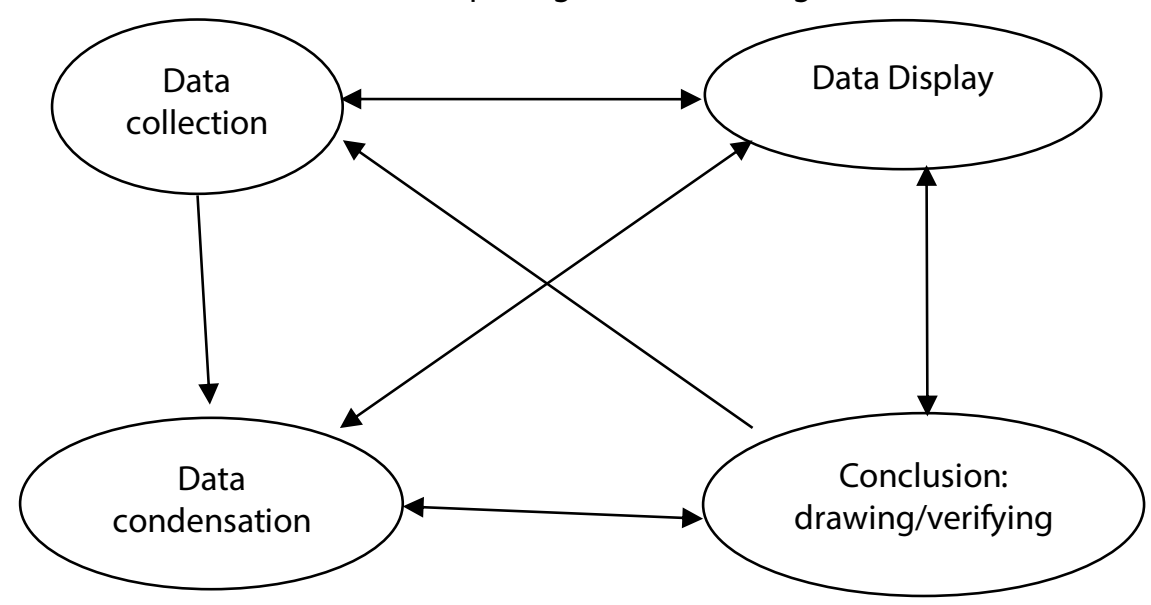

Gambar: Componen of Data Analysis: Interactive Model

(Miles M. B \&Huberman, A. M. \& Saldana, J. 2014)

\section{Hasil Penelitian dan Pembahasan}

Bagian-bagian yang akan dibahas pada bab ini sesuai dengan fokus penelitian yang meliputi; (1) perencanaan pimpinan pondok pesanntren kembentuk karakter multikultural santri, (2) strategi pimpinan pondok pesanntren ciptakan budaya organisasi membentuk karakter multikultural santri, (3) strategi pimpinan pondok pesanntren membentuk karakter multikultural santri. 
Perencanaan Pimpinan Pondok Pesanntren Membentuk Karakter Multikultural Santri

Perencanaan dalam suatu kegiatan adalah sesuatu y6ang sangat penting, dengan perencanaan yang matang dan tepat kegiatan akan berjalan dengan lancar bahkan perencaan merupakan fungsi manajemen yang pertama. Salah satu pendekatan perencanaan yang cukup efektif adalah perencanaan strtategik. Perencanaan strategik penentuan visi misi organisasi merupakan kegiatan utama. Sonhadji dan Huda AY.( 2015 : 89) menyatakan bahwa perencanaan strategik melibatkan aliran-aliran informasi baik yang berasal dari dalam organisasi maupun yang datang dari lingkungan. Dengan dasar analisa SWOT (strengths, weeknesses, opurtunities, threats) perencanaan strategik memiliki keunggulan: Prediksi masa depan yang tajam, arah organisasi yang sangat jelas, sangat memperhatikan perkembangan eksternal, evaluasi internal yang objektif, tujuan terukur, dan pemilihan strategi yang tepat. L. Morrisey George. (2007 : 6) Perencanaan strategis harus juga dengan pemikiran strategis yaitu kemampuan pemikiran intuitif ke depan. Pada perencanaan pendidikan terutama dalam merumuskan visi misi atau tujuan pendidikan karakter berbasis multikultural harus melibatkan berbagai pihak. Martin (2013:5) melibatkan pimpinan, guru, tenaga administrasi, masyarakat dan santri.

Perencanaan pimpinan pondok pesantren Darussalam Martapur, Ibul Amin Pemangkih dan Al Falah Banjarbaru melakukan perencanan sebagai berikut (1) pimpinan pondok pesantren melakukan perencanaan dengan dasar dan tujuan yang jelas dalam pembentukan akhlak/ karakter multikultural, (2) merumuskan tujuan, tata tertib, larangan, sanksi, kewajiban dan proses pelaksanan pendidikan untuk membentuk karakter multikultural, (3) merumuskan kurikulum yang memuat pelajaran akhlak/ karakter bersumber dari kitab-kitab akhlak. (4) merancang strategi dan mempertahankan kitab kuning sebagai sumber pembentukan akhlak/karakter multikultural.

Sehubungan itu Aqib, dkk (2011 :32) berpendapat bahwa penanaman karakter memiliki dua makna yaitu merencanakan program dan kegiatan penanaman karakter oleh lembaga pendidikan serta penanaman nilai-nilai karakter kepada para pembuat rencana itu sendiri yang memiliki keterkaitan antara unsur-unsur yang direncanakan. Unsur-unsur yang direncanakan meliputi (a) pengembangan nilai-nilai karakter pada kurikulum dan pembelajaran, (b) penanaman nilai-nilai karakter pada pendidik dan tenaga kependidikan, (c) penanaman nilai-nilai karakter melalui pembinaan peserta didik, (d) penanaman nilainilai karakter melalui manajemen sarana dan pra sarana pendidikan, (e) penanaman nilainilai karakter melalui manajemen pembiayaan pendidikan. 


\section{Strategi Pimpinan Pondok Pesantren Ciptakan Budaya Organisasi Membentuk Karakter Multikultural Santri}

Dalam menciptakan budaya organisasi pimpinan pondok pesantren Darussalam Martapura, pondok pesantren Ibnul Amin Pemangkih, pondok pesantren Al Falah Banjarbaru, dalam rangka membentuk karakter multikultural para santri yaitu; (1) berupaya mmepertahankan budaya organisasi yang sudah terbentuk sejak awal berdirinya pondok pesantren, (2) terbentuknya karakter multikultural santri bersumber pada kitab-kitab akhlak yang dipelajari yang wajib diimplementasikan dalam kehidupan sehari-hari. (3) Kitab yang dipelajari adalah kitab kuning, (4) Pengasuh adalah publik pigur kharismatik yang terbangun melalui proses interaksi yang cukup lama, (5) Membangun kometmen bersama untuk menerima dan menghargai teguran, nasihat dalam upaya membentuk karakter multikultural, (6) pembauran atau hidup berdampingan antara santri dengan pengasuh dan para guru sebagai orang tua santri,

Stephen P. Robbins (2006: 49) berpendapat bahwa dalam sebuah organisasi Seandainya orang-orang sedang menjadi lebih homogen, dapatlah kita mengambil suatu pendekatan bebas-budaya ke prilaku organisasi. Namun pendekatan semacam itu tampak tidak dibenarkan dimasa kini, karena alasan-alasan berikut: (1) Ada perbedaan-perbedaan dalam budaya-budaya nasional yang berlainan. (2) Perbedaan-perbedaan ini menjelaskan sebagian besar dari perbedaan sikap dan perilaku. (3) Dan sekurangnya untuk sekarang ini, dan agaknya untuk sejumlah tahun mendatang.

Moorhead, Gregory, W.Griffin, Ricky (2013:63). Menegaskan dalam membangun budaya organisasi juga perlu kometmen organisasi yaitu kometmen kerja, mencerminkan identifikasi dan ikatan seseorang individu pada organisasi. Seorang yang sangat berkometmen mungkin akan melihat dirinya sebagai anggota sejati dari lembaga. Tetapi perlu diingat bahwa individu dalam organisasi memiliki kepribadian. Kepribadian adalah serangkaian atribut psikologis yang relatif stabil yang membedakan satu orang dengan yang lain.

Pengertian yang sering dijadikan referensi dalam mendefinisikan komitmen organisasi seperti yang digambarkan oleh Kolter (2000), sebagai sifat hubungan seorang individu dengan organisasi yang memungkinkan seseorang dengan komitmen yang tinggi akan memperlihatkan keinginan kuat untuk menjadi anggota organisasi yang bersangkutan, kesediaan untuk berusaha sebaik mungkin serta penerimaan yang kuat terhadap nilai-nilai dan tujuan organisasi. Pengertian tersebut memberi arti adanya dua komitmen. Pertama, komitmen tehadap sasaran organisasi atau ke mana organisasi itu diarahkan, sehingga dengan komitmen tinggi, mereka akan bertahan sebagai anggota organisasi. Kedua, komitmen pada nilai-nilai, norma, dan budaya organisasi yang memberikan batasan yang boleh atau tidak boleh dilakukan, di mana hal tersebut 
memberi keyakinan teguh pada para anggotanya, sehingga akan menimbulkan komitmen teguh pula pada organisasi tempat bekerja. (A. Dirwan, $2014: 2$ )

Selain itu juga perlu dikembangkan afek dan suasana hati, pengembangan persepsi organisasi internal lembaga dan eksternal lembaga. Dalam lembaga pendidikan terjadi hubungan interpersonal dan hubungan antar kelompok. Semua itu akan mempengaruhi proses dan efektivitas organisasi ((L. Daft Richard 2006 :64).

\section{Strategi Kepemimpinan Pondok Pesantren Membentuk Karakter Multikultural}

Pemimpin dalam manajemen memegang peranan untuk menggerakan seluruh sumber daya yang ada pada organisasi(Robert Krietner, 1989: 9). Dalam hal ini pemimpin harus mampu mempengaruhi personelnya menuju pendidikan karakter yang berbasis multikultural. Manajemen tidak hanya dipandang sebagai ilmu, melainkan juga sebagai seni. Adalah Stoner (2006:15) menyatakan bahwa manajemen sebagai "The art of getting things done through people".

Strategi kepemimpinan pimpinan pondok pesantren salafiah Darussalam Martapura membentuk karakter multikultural santri adalah;

1) Pondok Pesantren menerima siapapun yang ingin menmba ilmu, tidak membedabedakan status sosial, ekonomi, warna kulit, suku dan bangsa.

2) Menggunakan tipe kepemimpinan kharismatik, dengan gaya demokratis dan dinamis situasional

3) Pimpinan dan para guru menunjukan sikap dan perilaku yang terbuka, peduli, hangat, menghargai perbeda, toliransi mengayomi, membimbing para santri.

4) Konsisten antara perkataan/ apa yang diajarkan dengan perbuatan.

5) Memberikan nasihat, motivasi, pembiasaan dan pengawasan.

Pimpinan ponpes dapat mengimplementasikan prinsip pendidikan multikultural yaitu upaya reformasi lembaga pendidikan, dirancang untuk meningkatkan pemerataan pendidikan untuk berbagai budaya, etnis, kelompok dan ekonomi "(Bank, 1993, p. 6, dalam Michael Vavrus 2006: 1) Pendidikan multikultural memiliki konsep semua peserta didik, tanpa memperhatikan gender, status sosial, suku, ras atau karakteristik budaya, wajib memperoleh kesempatan dan perlakuan yang sama untuk belajar di sekolah.

Dalam strategi perlu komptensi untuk pemimpin pendidikan karakter multikultural sebagaimana yang dikembangkan oleh McCall dan Hollenbeck (2002) sebagai berikut:

- Fleksibilitas dalam strategi dan taktik

- Sensitivitas Budaya

- Kemampuan untuk menangani kompleksitas

- Ketahanan dan akal 
- Kejujuran dan integritas

- stabilitas Pribadi

- Suara keterampilan teknis : ( Mery L. Connerley, Paul B Padersen, 2006 : 73)

Pemimpin (Pengasuh, Kepala Sekolah) sebagai tokoh sentral pendidik akan menjadi referensi orang-orang yang terlibat dalam kegiatan sekolah bersangkutan. "One of my teachers was such a towering personality that he radically changed the direction of my life, though I was scarcely aware of his influence at the time (Bryan R. Warnick, 2008 :1). Hasil penelitian menunjukan prsangka merupakan kendala utama bagi seorang pemimpin multikultural. Untuk itu perlu kerja keras untuk menghilangkan prasangka, itulah gagasan dalam upaya menjadi untuk menjadi pemimpin multiculturally kompeten. ( Mery L. connerlyy, Paul B Pedersen, 2005 : 15.). Pemimpin relegius bukan berarti pemimpin anti agama lain (T. Buchan Michael. 2013 : 105).

Prasangka baik terhadap semua orang akan mengembangakan sikap positif, baik dari yang bersangkutan maupun orang lain. Dalam prosesnya akan berkembang suasana yang memungkinkan terbentuknya saling menghargai dan menghornati meskipun kedua belah pihak masih belum saling kenal secara mendalam. Perasaan saling menghargai dan menghormati merupakan salah satu dasar bagi terbentuknya kebersamaan dalam menghadapi tantangan kehidupan berbangsa dan bernegara.

\section{Simpulan}

Perencanaan Pimpinan Pondok Pesanntren Membentuk Karakter Multikultural Santri yaitu; pimpinan pondok pesantren melakukan perencanaan dengan dasar dan tujuan yang jelas dalam pembentukan akhlak/ karakter multikultural, merumuskan tujuan, tata tertib, larangan, sanksi, kewajiban dan proses pelaksanan pendidikan untuk membentuk karakter multikultural, erumuskan kurikulum yang memuat pelajaran akhlak/ karakter bersumber dari kitab-kitab akhlak, merancang strategi dan mempertahankan kitab kuning sebagai sumber pembentukan akhlak/karakter multikultural.

Strategi Pimpinan Pondok Pesantren Ciptakan Budaya Organisasi Membentuk Karakter Multikultural Santri yaitu; pinpinan mempertahankan dan mengembangkannya sesuai tuntutan perkembangan jaman, kitab-kitab akhlak yang dipelajari yang wajib diimplementasikan dalam kehidupan sehari-hari, Pengasuh/ pimpinan sebagai publik pigur kharismatik, membangun kometmen 
bersama untuk menerima dan menghargai teguran, nasihat, pembauran atau hidup berdampingan antara santri dengan pengasuh dan para guru.

Strategi Kepemimpinan Pondok Pesantre Membentuk Karakter Multikultural Santri yaitu; menerima siapapun yang ingin menimba ilmu, tidak membeda-bedakan status sosial, ekonomi, warna kulit, suku dan bangsa, tipe kepemimpinan kharismatik, dengan gaya demokratis dan dinamis situasional, menunjukan sikap dan perilaku yang terbuka, peduli, hangat, menghargai perbeda, toliransi mengayomi, membimbing para santri, konsisten antara perkataan/ apa yang diajarkan dengan perbuatan, memberikan nasihat, motivasi, pembiasaan dan pengawasan.

\section{Referensi}

Achmad Fedyani Saefuddin. 2006. "Membumikan Multikulturalisme di Indonesia" dalam Jurnal Antropologi Sosial Budaya ETNOVISI. Volume 2, Nomor 1.

Arthur. J. 2008. Traditional Approaches to Character Education in Britain and America.James ArthurLarry P. Nucci and Darcia Narvaez(Ed) 2008.Handbook of Moral and Character Education. New York:by Routledge.

Bedjo Sujanto. 2007. Cet. I. Pemahaman Kembali Makna Bhineka Tunggal Ika Persaudaraan dalam Kemajemukan. Jakarta: CV. Sagung Seto.

Blum L. 2010. Secularism, multiculturalism and same-sex marriage: a comment on Brenda Almond's 'Education for tolerance,Journal of Moral Education 39. Routledge. (2), 145-160:

Bungin, B. 2009.Penelitian Kualitatif: Komunikasi, Ekonomi, Kebijakan, dan IImu Sosial Lainnya. Jakarta: Prenada Media Group.

Buchan, M.T. 2013. Leadership and Relegius Schools International Percpectives and Callenges.New York, London, New Delhi, Sydney. Bloombury.

Milles, dkk. 2014.Qualitative data analisys: a methods sourcebook. Third Edition.Arizona State University.Sage.

Connerley, M.L. \&Padersen P. B. 2005.Leadership in a Diverse and Multicultural Enveronment, Developing Awereness, knowledge and Skills, Sage Publications London, New Delhi.

Cockburn, A.D. 2013, Headteachers, MediocreColleagues and theChallenges of EducationalLeadershipReflections on Teacher Quality, University of East Anglia, MacMilan.

Carr, D. 2008. Character Education as the Cultivation of Virtue (100115)DalamLarry P. Nucci and Darcia Narvaez(Ed) 2008. Handbook of Moral and Character Education. New York:by Routledge.

Dirwan, A. 2015. Pengaruh Budaya Organisasi dan Komitmen terhadap Kinerja Dosen Perguruan Tinggi Swasta.Jakarta: Jurnal Ilmu Pendidikan, 21(1), 18. 
Doty, J .2006. Sports Build Character?!.Journal of College \& Character Volumevii, No. 3, April 2006.

Daulay, Haidar Putra. 2001. Historis dan Eksistensi Pesantren, Sekolah, dan Madrasah, Yogyakarta: Tiara Wacana

Choirul Mahfud. 2006. Pendidikan Multikultural. Yogyakarta : Pustaka Pelajar.

Imron, A. 2012.Kebijaksanaan Pendidikan di Indonesia Proses, Produk di Masa Depan.Jakarta: Bumi Aksara.

Lickona, T. 2015. Character Matters.Jakarta: Bumi Aksara.

Mukhadis, A. 2015.Kiat Menulis Karya Ilmiah, Malang: Aditya Media Publishing.

Qomar, Mujamil. 2002. Pesantren Dari Transformasi Metodologi Menuju Demokratisasi Institusi. Jakarta: Erlangga.

Sa'dan, M.2015 Jurnal TOLERANSI: Media Komunikasi Umat Bergama, Vol.7, No.1 Januari-Juni 2015

Ulfatin, N. 2015.Metode Penelitian Kualitatif di Bidang Pendidikan, Malang: MNC Publishing.

Vessels, G., \& Huitt, W. (2005).Moral and character development. Paper presented at the National Youth at Risk Conference, Savannah, GA, March 8-10. Retrieved [date], from http://www.edpsycinteractive.org/papers/chardev.pdf

Vavrus, M.2002,TransformingtheMulticultural Educationof TeachersTheory, Research, and Practic,Foreword byMary DilworthTeachers CollegeColumbia UniversityNew York and London.

Warnick, Bryan R. 2008. Imitation and EducationA Philosophical Inquiry into Learning by Example. New York: State University of New York Press, Albany.

Wattarasook, W. 2013, Multi-cultural Education Management.GSE e-Journal of Education.E-ISSN 2289-6889. Hal 99-103.Organized by WorldConferences. 